\title{
30. THE LATE JURASSIC-EARLY CRETACEOUS GENUS CALPIONELLA IN REWORKED PEBBLES FROM DEEP SEA DRILLING PROJECT SITE 460, MARIANA TRANSECT ${ }^{1}$
}

\author{
Jacques Azéma, Département de Géotectonique, Université Pierre et Marie Curie, Paris, France \\ and \\ René Blanchet, Laboratoire d'Océanologie et Géodynamique, Université de Bretagne, Brest, France
}

The upper Eocene-upper Oligocene sequence drilled in Hole 460 , Leg 60 , is a pebble conglomerate with crystal calcareous mud. A thin section of one of the pebbles (Plate 1) was made on shipboard. This rock fragment was itself a conglomerate with small pebbles in a volcaniclastic matrix. Some of the pebbles are siliceous and radiolarian-rich and others are calcareous and contain microfossils with the general aspect of the genus Calpionella.

Unfortunately the thin section was lost and only photographs remain. Some of these fossils are small (less than $100 \mu \mathrm{m}$ ), consisting of a small chamber with axial symmetry and lacking ornamentation. The chamber narrows to a short, straight cylindrical neck which is open at the distal end. These last characteristics indicate Calpionella alpina Lorenz, which ranges from late Tithonian to Berriasian.

Calpionellids are planktonic microfossils (Remane, 1971). Their biological affinity has not yet been definitively established, but they are thought to be protozoans. Nevertheless, they are excellent time indicators (Allemann et al., 1971). They are restricted to the period between the Late Jurassic to early Valanginian. They

\footnotetext{
1 Initial Reports of the Deep Sea Drilling Project, Volume 60.
}

have been described from the Tethyan realm from the Himalayas (Gansser, 1964) in the east, to Mexico (Trejo, 1975) and Venezuela (Bermudez and Rodriguez, 1962; Furrer, 1972) in the west. The possible existence of the genus Calpionella in the western Pacific establishes the age of the oldest sediment recovered on Leg 60 and would be a key element in indicating some Tethyan affinities. But this indication must be verified by samples from other sites as well as from outcrops on land in the same area.

\section{REFERENCES}

Allemann, F., Catalano, R., Farès, F., et al., 1971. Standard Calpionellid zonation (Upper Tithonian-Valanginian) of the western Mediterranean Province. Proc. II Plankt. Conf., Roma 1970 (Vol. 2): Rome (Ediz. Tecnoscienza), 1337-1340.

Bermudez, P. J., and Rodriguez, D., 1962. Notas sobre la presencia de Tintinidos o Calpionelas en Venezuela. Bol. Inf. Asoc. Venez. Geol. Min. Pet., 1/2:51-57.

Furrer, M. A., 1972. Fossil Tintinnids in Venezuela. Mem., VI Conf. Geol. del Caribe, Margarita, Venezuela, pp. 451-454.

Gansser, A., 1964. Geology of the Himalayas: London (Wiley-Interscience).

Remane, J., 1971. Les Calpionelles, Protozoaires planctoniques des mers mésogéennes de l'époque secondaire. Ann. Guébhard, 47:125.

Trejo, M., 1975. Tintinidos mesozoicos de Mexico (Taxonomia y Datos Paleobiologicos). Bol. Asoc. Mex. Geol. Pet., 27(10-12): 329-449. 

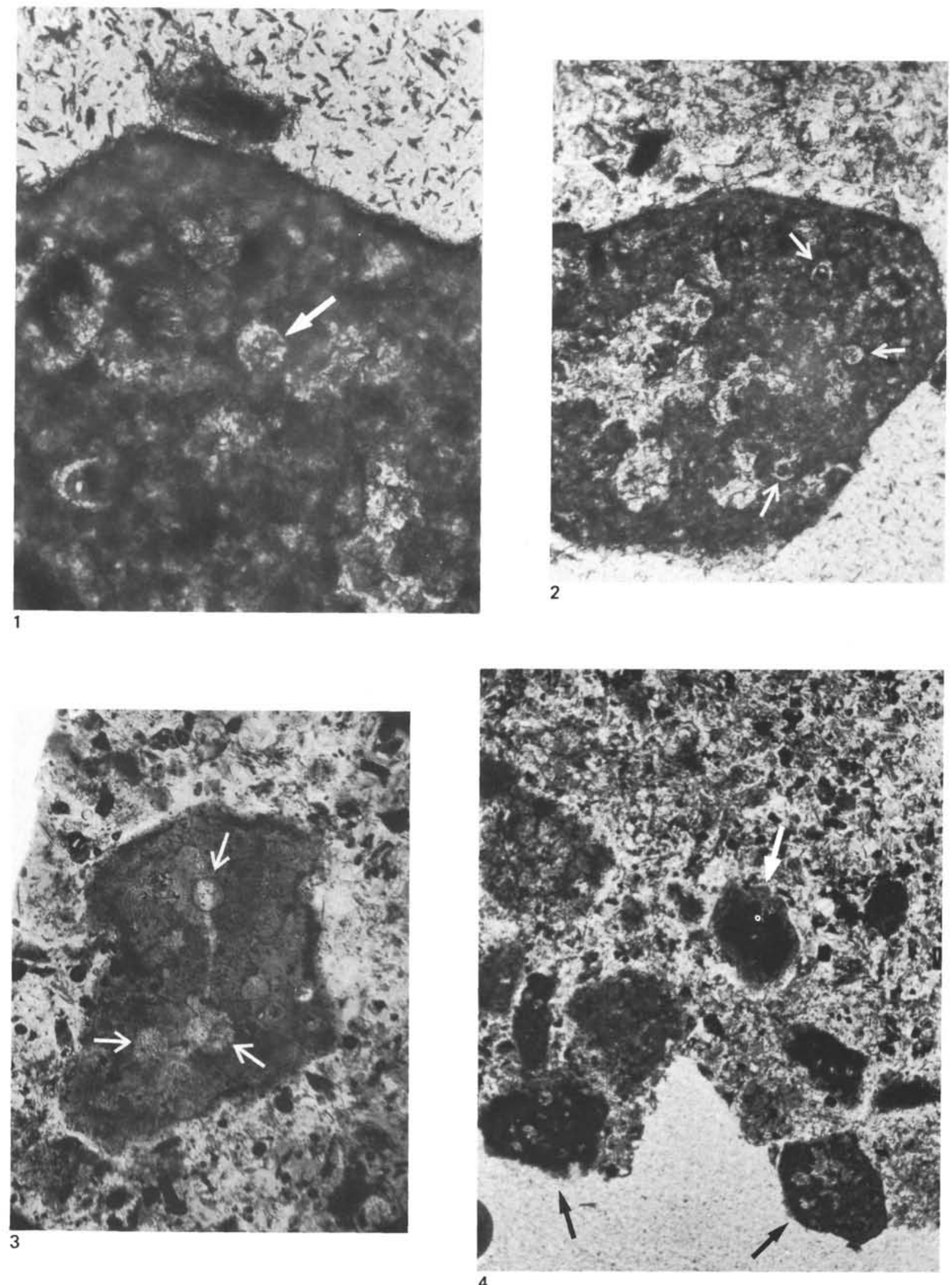

Plate 1. Thin section of pebble conglomerate, Sample 460-5-1, 30-32 $\mathrm{cm}$.

Figure 1. Pebbles reworked in a volcano clastic matrix.

Figure 2. A piece of chert with radiolarians (Cretaceous?).

Figures 3 and 4 . Arrows show some sections of probable Calpionellids. 